\title{
Actos y contratos sobre el derecho a la imagen en el ordenamiento chileno (con referencia al derecho comparado)
}

\author{
Cristián Larrain Páez*
}

\section{RESUMEN}

El artículo tiene como objetivo identificar los antecedentes normativos que justifiquen la legitimidad de actos y contratos sobre el derecho a la imagen, en el ordenamiento nacional. Esto, teniendo presente que se lo suele considerar un derecho de la personalidad, y por tanto irrenunciable e inalienable. A su vez, aborda los problemas que se presentan ante una eventual revocación de una autorización prestada, y los que se pueden manifestar cuando el titular del derecho es un menor.

$$
\text { Imagen - personalidad - contrato }
$$

\section{Contracts involving the right to one's image in Chilean Law (with reference to foreign Law)}

\begin{abstract}
The article aims to identify a legal background that can justify the celebration of contracts involving the right to one's image in the Chilean Law. This, under the consideration that implies that this right usually is considered a "personality right", therefore, inalienable. Among these, the exposition also focuses on the possibility of revoking the authorization, and on the problems involving authorizations for using images of infants.
\end{abstract}

$$
\text { Image - personality - contract }
$$

* Doctor en Derecho, Universidad Carlos III de Madrid. Profesor de Derecho Civil de la Universidad de Concepción. Correo electrónico clarrain@udec.cl. Este trabajo se ha realizado dentro del marco del Proyecto de Investigación Fondecyt N 11130393 (Iniciación en Investigación).

Artículo recibido el 26 de noviembre de 2015 y aprobado para su publicación el 1 de marzo de 2017. 


\section{INTRODUCCIÓN}

$\mathrm{E}$ 1 derecho a la imagen suele ser conceptualizado como el derecho a que nadie capte, difunda o utilice la imagen de una persona sin su consentimiento ${ }^{1}$. Desde esta perspectiva, en la práctica se configura como una prerrogativa que protege a los individuos frente al empleo no autorizado de cualquier forma de reproducción gráfica de su figura, que permita de alguna manera su identificación ${ }^{2}$. Su transgresión se puede materializar en fotografías, filmaciones e incluso pinturas, por medio de soportes tanto físicos como digitales ${ }^{3}$. En todos estos supuestos lo relevante es que se reproducen los rasgos físicos de una persona, con un nivel de precisión que permite su identificación. Tradicionalmente se lo califica como derecho de la personalidad, y comparte por tanto ciertas características comunes de esa clase de derechos, que orbitan sobre el denominador común de ser irrenunciables, y que se reflejan en la práctica, en ser además intransferibles e intransmisibles ${ }^{4}$. En consecuencia, sería susceptible de ser calificado también como un derecho incomerciable, circunstancia que ameritaría dudas respecto de su admisibilidad como objeto de actos jurídicos en nuestra legislación ${ }^{5}$. Ahora, este carácter que apunta teóricamente a una incomerciabilidad de dicho derecho se contradice con la realidad, en la que las personas, con diferentes finalidades y en distintos escenarios, permiten que sus imágenes sean empleadas por terceros. En mayor o menor medida, en nuestro país se están celebrando actos jurídicos que tienen por objeto el derecho a la imagen de

${ }^{1}$ Igartua, F. "El derecho a la imagen en la jurisprudencia española”, en Salvador, P. (dir.), El mercado de las ideas, Centro de Estudios Constitucionales, Madrid, 1990, p. 319.

${ }^{2}$ En otras palabras, se trata de un derecho subjetivo que concede a su titular el monopolio sobre el uso y explotación de su propia imagen.

${ }^{3}$ La imagen, en estos casos, es el retrato del sujeto, contenido en un soporte físico o digital. Y el derecho a la imagen es el que le concede a aquel la facultad de controlar la captación, difusión y explotación de ese retrato.

${ }^{4}$ Alessandri R., A; Somarriva U., M. Curso de Derecho Civil. Parte General y los Sujetos de Derecho, por Antonio Vodanovic H., Editorial Nascimento, Santiago, 1971, p. 291. En el mismo sentido, Peña, J.I. “El derecho a la propia imagen en la doctrina y jurisprudencia chilenas", en Revista de Derecho Público, n 63, tomo I, 2001, pp. 295-299; Nogueira, H. "El derecho a la propia imagen como derecho fundamental implícito. Fundamentación y caracterización”, en Revista Ius et Praxis, $\mathrm{n}^{\circ} 2$, 2007, pp. 269-270. En la doctrina comparada, estos caracteres suelen predicarse en general para todos los denominados "derechos de la personalidad" (más allá de las diferentes justificaciones con las que ocasionalmente se explican los actos dispositivos sobre algunos de ellos), véanse por ejemplo: Castán, J. "Los derechos de la personalidad”, en Revista General de Legislación y Jurisprudencia, vol. XXIV, $\mathrm{n}^{\circ}$ 1-2, 1952, pp. 22-23; Concepción Rodríguez, J.L. Honor, intimidad e imagen, Bosch, Barcelona, 1996, p. 61; De Ángel, R. "La protección de la personalidad en el Derecho Privado", en Revista de Derecho Notarial (XXI), n LXXXIII, 1974, pp. 51-52; De Cupis, A. I Diritti della Personalità. Giuffrè, Milán, 1959, tomo I, pp. 78 y sgtes.; Kayser, P. "Le droits de la personnalité. Aspects Théoriques et pratiques”, en Revue Trimestrielle de Droit Civil, 1971, vol. 69, p. 493.

${ }^{5}$ No es poco frecuente encontrar afirmaciones que defienden que el derecho a la imagen no puede ser objeto de un acto de disposición, al menos como el que se conoce tradicionalmente en Derecho Patrimonial. En este sentido en la doctrina italiana, Galgano por ejemplo. El autor entiende que el acto sería "nulo por imposibilidad del objeto", y justifica los negocios sobre la imagen indicando que en esos supuestos se trata del consentimiento prestado en un acto jurídico diferente, ajeno a la lógica contractual tradicional. Galgano, F. Diritto Civile e Commerciale, Cedam, Padova, 2004, vol. I., p. 181. 
personas, dentro o fuera del estatuto contractual ${ }^{6}$, y esta realidad requiere ser compaginada con el postulado que, aplicado literalmente, conduciría al absurdo de que esos negocios jurídicos adolecerían de nulidad absoluta por ilicitud de objeto.

En ese contexto, el presente trabajo $^{7}$ tiene por objeto determinar e identificar antecedentes normativos que justifiquen la legitimidad de actos jurídicos cuyo objeto sea el derecho a la imagen en nuestro país, teniendo a la vista las opiniones de la doctrina nacional y comparada, y las soluciones a las que han llegado nuestros Tribunales Superiores, cuando se les han presentado conflictos acerca de esa materia. Dentro de las cuestiones íntimamente relacionadas con este tema se abordará además el problema de la revocación de la autorización (en el sentido de si es o no procedente) y el de la legitimación para prestar el consentimiento, cuando se trata de imágenes de menores.

\section{ASPECTOS PRELIMINARES: AUTORIZACIÓN Y TRANSFERENCIA}

En primer lugar es necesario aclarar ciertas cuestiones en forma previa. El acto por el que una persona dispone de su derecho a la imagen puede ser unilateral o bilateral. Este último a su vez puede o no ser un contrato, según sus términos específicos ${ }^{8}$. En todos esos casos el titular del derecho manifiesta su voluntad permitiendo a un tercero realizar cierta conducta que, sin ella, sería ilícita. No obstante los matices teóricos que se pueden presentar entre las diferentes categorías señaladas en materia de formación del negocio jurídico y en el plano obligacional (para el caso en que sea un contrato), en principio estos no debieran alterar las conclusiones a las que se pueda arribar en relación con el problema ahora planteado (si es lícito o no celebrar actos y contratos que tengan por objeto el derecho a la imagen). Donde sí puede haber diferencias es en relación con la finalidad con que el titular manifieste su voluntad. Hipotéticamente, en la práctica esa manifestación puede estar dirigida y limitada a que el tercero haga uso del derecho utilizando la imagen de la persona para un determinado fin. $\mathrm{O}$, por otra parte, el titular podría obligarse a transferir el derecho a la imagen, caso en el que el adquirente -pretendidamente- pasaría a ser el titular del derecho, y podría disponer de él a su arbitrio. En ambas alternativas se presentan dudas respecto de la licitud de esos actos, y deben ser enfrentadas en forma aislada, atendido que el supuesto carácter de irrenunciable e indisponible del derecho a la imagen podría considerarse independiente a su calidad de intransferible. Dicho de otra manera, es diferente que se permita (legítimamente) a

${ }^{6}$ Piénsese en actores de cine y televisión, modelos, deportistas, y en general todos quienes permiten que su cuerpo sea fotografiado o filmado para promocionar productos de toda clase (y sobre todo, quienes hacen de la "farándula" su profesión habitual), e incluso en simples particulares, que aceptan que sus rasgos físicos sean reproducidos y luego difundidos en redes sociales y en otros medios similares.

${ }^{7}$ Que forma parte de una investigación más amplia, cuyos resultados quedaron plasmados en otro artículo, que se refiere a los aspectos generales del derecho a la imagen, y en particular a las consecuencias jurídicas de su uso no autorizado, específicamente en materia de Responsabilidad Civil.

${ }^{8}$ El que también podrá ser, según el caso, unilateral o bilateral, según si resultan obligadas o no ambas partes. 
un tercero que utilice la imagen de una persona con una determinada finalidad, a que se le entregue su explotación en forma exclusiva y perpetua a otra persona, o más aún, pretender enajenar el derecho. En el primer caso, se suele hablar de autorización -o de consentimiento si el acto es bilateral (o un contrato)-, y en el segundo, derechamente de transferencia. En ese contexto, a continuación se expondrá para ambas alternativas las propuestas teóricas que ha elaborado la doctrina al evaluar su legitimidad.

\section{Autorización}

En primer lugar, y en relación con la autorización (o consentimiento) ${ }^{9}$, se han propuesto distintas explicaciones que permitirían obviar teóricamente la incompatibilidad del carácter irrenunciable e indisponible del derecho a la imagen, y admitir la legitimidad de actos sobre dicho objeto. Dentro de estas se pueden destacar las siguientes: la primera, se resume en que el acto de autorización operaría como una causal de justificación (o de “exclusión de la ilegitimidad”), elevándolo al mismo nivel del "interés público" ${ }^{10}$, tesis que ha generado adeptos entre los autores nacionales ${ }^{11}$, y que pese a no estar exenta de críticas $^{12}$, tiene también una amplia acogida en la doctrina española ${ }^{13}$. La segunda consiste en que la autorización en realidad es el ejercicio del derecho de la personalidad en cuestión, el que permitiría, por definición, autorizar -o no- determinados actos protegidos por la prerrogativa ${ }^{14}$, construcción a la que se le ha objetado trasladar el mecanismo

${ }^{9}$ Según si se trata de un acto jurídico bilateral o unilateral, según el caso.

${ }^{10}$ Así se insinúa en España por Igartua (n. 1) p. 324.

${ }^{11}$ Siguen esta tesis: Corral, H. "La vida privada y la propia imagen como objetos de disposición negocial”, en Revista de Derecho de la Universidad Católica del Norte, $\mathrm{n}^{\circ}$ 8, 2001, p. 163; Nogueira (n. 10) p. 270 (aunque luego indica que cuando se "consciente en el uso de la imagen se está ejerciendo el derecho a la imagen en su sentido positivo”, p. 272); y Peña, J. I. "El derecho a la propia imagen en la doctrina y jurisprudencia chilenas”, en Revista de Derecho Público, no 64, 2002, p. 295.

${ }^{12}$ Clavería, en el contexto normativo español (la Ley Orgánica 1/1982 de Protección Civil del Derecho a Honor, a laIntimidad Personal y Familiar, y a la Propia Imagen, contiene normas relativas al consentimiento del titular del derecho), señala que esa tesis sería incorrecta, ya que coloca en un mismo plano lo que debe hallarse en dos diferentes: el Ordenamiento debe perfilar, en efecto, qué intromisiones o revelaciones admite y cuáles no y si la presencia de interés público convierte en legal lo que sin él no lo sería, pero siempre partiendo del supuesto de inexistencia de consentimiento del afectado; cuestión diversa es el supuesto de que tal consentimiento concurra, lo que genera la necesidad de establecer un régimen destinado a ello: el consentimiento no es, a mi juicio, un elemento configurador del supuesto $X$ (como sucede con el interés público), sino generador del supuesto $Y$, en cuanto que altera las bases del problema y provoca la necesidad de un régimen completo diferente. Clavería, L. H. "Negocios jurídicos de disposición sobre los derechos al honor, la intimidad y la propia imagen”, en Anuario de Derecho Civil, vol. XLVII, n III, 1994, pp. 41-42.

13 Entre otros, Concepción Rodríguez, (n 10) pp. 122-123; De Verda y Behamonte, J. R. "El consentimiento como causa de exclusión de la ilegitimidad de la intromisión”, en De Verda y Behamonte, J.R, El Derecho a la Imagen desde todos los puntos de vista, Thomson Reuters, Navarra, 2011, p. 67; Grimalt, P. La protección civil de los derechos al honor, a la intimidad y a la propia imagen, Iustel, Madrid, 2007, p. 104; Rovira, M. E. "El derecho a la propia imagen: Configuración legal y límites", en Revista de Derecho Privado, $\mathrm{n}^{\circ} 2$, 1998, p. 164; e Yzquierdo, M. "Daños a los derechos de la personalidad (honor, intimidad y propia imagen)", en Reglero, L., Tratado de responsabilidad civil, $5^{\text {a }}$ edición, Thomson Aranzadi, Navarra, 2014, p. 1.425.

${ }^{14}$ Es lo que se propuso en su oportunidad por Gitrama, antes de la entrada en vigor de la actual Constitución española y la legislación especial sobre la materia (Gitrama, M. "Voz 'imagen (derecho a la propia)”, en Mascareñas, C.; Pellisé, B. Nueva Enciclopedia Jurídica, Seix, Barcelona, 1979). 
de la autorización al terreno de la libertad y la autonomía personal, que son diferentes ${ }^{15}$. La tercera se explica en que el acto autorizante es el ejercicio de un derecho patrimonial "de explotación económica o comercial de la intimidad o propia imagen”, que es diferente al derecho fundamental ${ }^{16}$, elaboración que no deja de ser atractiva (y que emula al Right of Publicity norteamericano $)^{17}$, pero que discutiblemente se podría invocar en Chile. Así como se plantea, se trataría de un derecho real (para que fuese eficaz, tendría que tratarse de una prerrogativa oponible a toda la sociedad $)^{18}$, y en nuestro contexto los derechos reales estarían sujetos a reserva legal (a menos que se defienda que en realidad, lo que se invoca es el derecho de propiedad sobre un bien inmaterial -la imagen de la persona-, elaboración seductora pero que patrimonializa excesivamente un derecho cuyo sustrato es extrapatrimonial). Una cuarta alternativa distingue la autorización unilateral prestada para un uso no económico de la imagen, caso en el que sería una suerte de renuncia al derecho que impediría la ilicitud ${ }^{19}$; y por otro lado el contrato por el que una persona explota su imagen, hipótesis en la que se trataría del ejercicio de una legítima autonomía negocial sobre facultades jurídicas de rango ordinario en el marco de un contrato atípico ${ }^{20}$. Sin perjuicio de que esta explicación parece coherente en el plano contractual, adolece de una inconsistencia en el ajeno al contrato, ya que el acto de renuncia al derecho, en principio, no sería admisible (y si lo fuese, no se ven motivos para discriminar entre una explotación económica, de un uso ajeno a esa finalidad).

Si bien es posible encontrar otras construcciones doctrinales respecto de la cuestión ${ }^{21}$, en el contexto chileno parece razonable justificar (y por tanto admitir la licitud)

\footnotetext{
15 Corral (n. 15) p. 163.
}

16 Reseñada en Clavería (n. 16) p. 42. En sentido similar entre los autores franceses, Ollard, R. "Qualification de droits extrapatrimoniaux", en Saint-Pau, J.C., Droits de la Personnalité, Lexisnexis, Paris, 2013, pp. 302-303.

${ }^{17}$ Propuesta con esa referencia en Igartua (n. 1) pp. 321-324

${ }^{18} \mathrm{Al}$ respecto, debe tenerse presente que hay quienes entienden que los derechos de la personalidad son personales, y no reales (véase Guzmán, A. Las cosas incorporales en la doctrina y en el Derecho Positivo, Editorial Jurídica de Chile, Santiago, $2^{a}$ edición p. 85 y sgtes). Pero también, que en el caso de los derechos personales también se presentaría un "sujeto pasivo universal", atendida la imposición a los terceros de abstenerse de interferir en ellos, afirmación que relativizaría la crítica.

${ }^{19}$ Con esta explicación se justifica la disponibilidad (más nunca la transferencia) en Goubeaux, G. Traité de Droit Civil sous la direction de Jaques Ghestin. Les personnes, Librairie générale de droit et de Jurisprudence, París 1989, p. 257.

${ }^{20}$ Clavería (n. 16) p. 50.

${ }^{21}$ Así por ejemplo entre la doctrina francesa se puede encontrar una construcción que objeta la confusión de la persona, con su imagen, en el sentido de que no debiera confundirse a la imagen, con la cosa misma que ella representa. La imagen captaría solo la "apariencia física de la persona", pero no la persona misma (véase Castaldi C. L'Exploitation commerciale de l'Image des personnes physiques, Bruylant, Bruselas 2008. p. 14, autor que defiende que la imagen de las personas puede ser objeto de comercio contractual, observando que la construcción que impide la disponibilidad de la imagen se sustentaría en una premisa que califica de "primitiva", ya que descansaría sobre la afirmación de que la imagen sería una prolongación de la persona humana [p. 12]). Actualmente, la jurisprudencia de ese país acepta la celebración de contratos que tienen por objeto la imagen de una persona, al menos en relación con sus aspectos patrimoniales (véase Hassler, T. Le droit à l'image des personnes: entre droit de la personnalitè et propriété intellectuelle, LexisNexis, Estrasburgo, 
de los actos o contratos que contienen autorizaciones a terceros para ejercer el derecho a la imagen, en donde la manifestación de voluntad del titular implicará una "causal de justificación” que, al igual que el interés público, excluye la ilicitud. De esta forma se le reconoce al titular del derecho el poder de decidir qué intromisiones serán lícitas y cuáles no, circunstancia que no obstaría con su carácter de irrenunciable (en consideración a que no se está desprendiendo del derecho, ni inhibiéndose de continuar ejerciéndolo).

\section{Transferencia}

Hipótesis diferente a la anterior es la que se puede presentar en el caso de una pretendida cesión o transferencia del derecho a la imagen, con el objeto de que un tercero (o su cesionario) lo ejerza con prescindencia de la voluntad del titular original (quien queda además, inhibido de ejercerlo). En este supuesto, el carácter de irrenunciable e inalienable del derecho, sea originalmente o como un derivado o accesorio del derecho fundamental a la intimidad, impiden que un sujeto se desprenda de él. Este problema fue el que motivó la primera sentencia (y que lo consagró) sobre el Right of Publicity en Estados Unidos, ya que resolvió precisamente un problema entre dos supuestos cesionarios del derecho a explotar comercialmente las imágenes de ciertos deportistas ${ }^{22}$. Sin embargo, lamentablemente la experiencia norteamericana respecto de esta materia no es

2014 , p. 24). En el derecho italiano, por su parte, hay quienes entienden que se trata de una disposición parcial del derecho (y no del derecho mismo), interpretando a contrario el artículo 96 de la Ley de Propiedad Intelectual, que exige la autorización de la persona retratada para disponer de su imagen (Agate, A. "Il Diritto all'Immagine", en Ruscica, S. I Diritti della personalità, Wolters Kluwer, Lavis, 2013, pp. 561-562). En la doctrina española, la construcción más acabada acerca de este tema descansa en el postulado de que en el caso de los derechos subjetivos sujetos a un régimen jurídico de intransmisibilidad, su titular dispone de la posibilidad de constituir una relación jurídica con otra persona, y por la cual esta obtendrá un permiso para realizar una conducta que, de otro modo, sería ilicita. Así, el consentimiento o autorización para la intromisión no es solo, pues, expresión de un poder de disposición; sino también un instrumento de creación y autorregulación de una relación jurídica entre autorizante y autorizado. En este sentido, puede afirmarse que el consentimiento o autorización para la intromisión en derechos e intereses jurídicos subjetivos es -en tanto que acto de autonomía privada que reglamenta la relación entre autorizante y autorizado- un negocio jurídico (Vendrell, C. El Mercado de los Derechos de Imagen, Thomson Reuters, Navarra, 2014, pp. 268-269). De esta forma, más que una causal de justificación o mecanismo neutralizador de un ilícito, el consentimiento o autorización sería un cauce de regulación de intereses entre autorizante y autorizado (Vendrell p. 253) que permite desarrollar conductas determinadas, con cierto nivel de vinculación, incluso en caso de derechos no susceptibles de ser enajenados. Esta última construcción (elaborada buscando adecuar las particularidades teóricas del derecho a la imagen, a la La Ley Orgánica 1/1982 española, que contiene normas respecto de este tema), además de considerar a la autorización como un mecanismo legitimador de la intromisión, le concede un valor adicional, considerándola un verdadero acto jurídico, carácter que tiene relevancia en el contexto normativo español, sobre todo a propósito del análisis de una autorización otorgada en un contexto contractual, y al momento de evaluar la procedencia y consecuencias de una eventual revocación del consentimiento.

${ }^{22}$ El caso que lo motivó se denomina Haelan Laboratories, Inc. V. Topps Chewing Gum, Inc., y data de 1953. Sin embargo, el denominado Right of Publicity (que protege la explotación comercial de imágenes de las personas en Estados Unidos) ya era considerado - en otras configuraciones-antes de esta sentencia en Estados Unidos. El mérito de ella fue que reconoció a esa prerrogativa el carácter de enajenable. Véase Westfall, D.; Landau, D. "Publicity Rights as Property Rights", en Cardozo Arts E Entertainment, vol. 23, 2005, p. $76-77$. 
fácil de "importar" a ordenamientos con tradiciones como las del nuestro, considerando la naturaleza híbrida que tiene esa prerrogativa en dicho país (donde la tensión entre el Derecho de Propiedad y el Derecho a la imagen se presentó en los primeros esbozos de lo que vendría a ser hoy el Right of Publicity en Estados Unidos, y es hasta hoy un tema polémico $)^{23}$, en la que además priman de sobremanera aspectos netamente patrimoniales. La condición de irrenunciable e intransferible que se suele atribuir a los derechos de la personalidad apunta a rechazar -teóricamente- que una persona pueda desprenderse de un derecho de esa naturaleza. En consecuencia, no admite más que asumir esa condición para el derecho a la imagen.

Sin embargo, la experiencia práctica ha forzado a la doctrina a idear distintas fórmulas con las que se intenta justificar la existencia de un mercado lícito de imágenes, las que no serían incompatibles con la condición de inalienable que se atribuye al derecho a la imagen. Dentro de estas destaca la posición que explica que una cosa es el derecho (en singular) a la propia imagen y otra serían los derechos (en plural) de imagen, de manera semejante al uso lingüístico que diferencia el empleo de la expresión derecho de autor (en singular) y derechos de autor. El singular en ambos casos designaría el derecho madre o el monopolio jurídico que tiene toda persona sobre su propia imagen. El término usado en plural denotarían los frutos, lo royalties o rendimientos derivados de su explotación en el mercado ${ }^{24}$. Bajo este prisma, incluso en los contratos en los que se pretende "ceder" el derecho a la imagen a un tercero, la prestación queda restringida a sus frutos o productos, y la manifestación de voluntad del sujeto debe ser interpretada como una simple autorización, que se ha insertado en una relación contractual (considerando, en todo caso, la dificultad que implica incardinar el reconocimiento de frutos y productos en un plano en principio, ajeno a la patrimonialidad). Una lectura quizás más acertada observa que la imposibilidad de celebrar negocios jurídicos que tengan por objeto la transferencia del derecho, si bien restringe la autonomía privada del titular, no impide la celebración de negocios meramente obligacionales. Esto significa que el contrato por el que el titular de los derechos fundamentales de la personalidad incorporal autoriza para la intromisión en sus derechos deberá, forzosamente, ser considerado como un negocio meramente obligacional o de obligación; sin que pueda configurarse como un negocio de disposición y, en particular, como una de las manifestaciones más importantes de esta categoría, como es el contrato transmisivo. De ello se desprenden consecuencias prácticas muy significativas respecto de la posición que adquiere el beneficiario del consentimiento o autorización por medio de su contrato con el titular de los derechos fundamentales de la personalidad incorporal ${ }^{25}$. Esta tesis parece más adecuada a la realidad práctica, y se inserta con mayor coherencia en el

${ }^{23}$ Véase por ejemplo, lo desarrollado en Westfall y Landau (n. 30), pp. 71 y sgtes.

${ }^{24}$ Rodríguez, J.M. “Autorización y cesión: el consentimiento para la intromisión en derechos inalienables”, en Cabanillas, A.; Caffarena, J.; et al., Estudios jurídicos en homenaje al profesor Luis Díez-Picazo, tomo I, Thomson Civitas, Navarra, 2003, p. 865. Una propuesta parecida (pero sin mayor desarrollo) hace Nogueira, quien entiende que el objeto del contrato no es el derecho a la imagen, sino que "intereses patrimoniales que derivan del derecho a la propia imagen” (Nogueira, P. El derecho a la propia imagen, Librotecnia, Santiago, 2010, p. 108).

${ }^{25}$ Vendrell (n. 8) p. 418. 
marco teórico en el que se encuadran los derechos de la personalidad. En consecuencia, la autorización será parte del objeto de un contrato, que en caso alguno implicará la enajenación o transferencia del derecho a la imagen, sino que solo un efecto obligacional (al menos, un deber de abstención y tolerancia por parte del titular originario).

\section{Derecho CHILENO}

En nuestro país, la cuestión ha recibido una tibia atención por parte de la doctrina (que suele manifestarse en sentido favorable a la autorización de actos que tengan por objeto el derecho a la imagen $)^{26}$, y más allá de las conclusiones que se puedan obtener de las sentencias en las que se han resuelto problemas relacionados tangencialmente con actos de disposición, no es posible encontrar en sede jurisdiccional un precedente en que se aborden de manera crítica uno o más de los problemas enunciados en este trabajo.

\section{La jurisprudencia}

En efecto, todas las sentencias que se han podido encontrar discurren acerca de la ausencia de una autorización; concerniente a la existencia de una autorización (que implica en la práctica el rechazo de un recurso o demanda); o respecto de la desviación en el uso de la imagen a uno diferente del originalmente autorizado, pero ninguna en la que se haya discutido de la procedencia y validez de un acto autorizante ${ }^{27}$. Dentro de las resoluciones más llamativas en ese contexto merecen ser destacadas las siguientes:

a) El caso Salazar con Diario La Tercera de La Hora ${ }^{28}$ se resolvió con el rechazo de un recurso de protección interpuesto por una mujer que pretendía impedir que persistiese la publicación de ciertas fotografías que se había tomado años antes, a propósito de un reportaje en un centro invernal. La Corte rechazó el recurso, bajo el argumento de que no solo se había autorizado la captación y difusión de las imágenes, sino que además la recurrente había recibido una contraprestación

${ }^{26}$ Véase n. 15. Destaca además la posición de Barros, quien defiende que los bienes de la personalidad tendrían una doble dimensión: Desde un punto de vista moral, suponen la potestad de excluir a otros de un cierto ámbito personal; desde un punto de vista económico, permiten al titular el goce y disposición de los valores patrimoniales conexos a esa exclusividad, explicando la comerciabilidad de los derechos de la personalidad, en que supondría una renuncia a la privacidad que ella supone (lo privado devenga público), considerando a la prerrogativa como casi análoga al derecho de propiedad (Barros E. Tratado de Responsabilidad Civil, Editorial Jurídica de Chile, Santiago, 2006 pp. 564-565).

${ }^{27}$ De hecho, al menos en una oportunidad el Tribunal Constitucional afirmó, en una sentencia a propósito del derecho a la vida privada (respecto al cual, en esta materia, no habría inconvenientes en invocar soluciones análogas para el derecho a la imagen), que era posible evitar una intromisión mediante el consentimiento espontáneo de la misma persona (considerando $21^{\circ}$ de la sentencia rol 1.894-2011, de fecha 12 de julio de 2011).

${ }^{28}$ Sentencia de la Corte de Apelaciones de Santiago, del 21 de agosto de 1985 (Gaceta Jurídica n ${ }^{\circ}$ 62, 1985 , p. 58). 
pecuniaria por ello. Es posible identificar aquí un indicio de los efectos de lo que sería un contrato sobre la imagen de una persona, y al mismo tiempo, que en ese contexto no procedería la revocación de la autorización.

b) El caso Jara Pizarro con Polla Chilena de Beneficencia y otra ${ }^{29}$ recayó en un recurso de protección interpuesto por una mujer que, ejerciendo de modelo profesional, había celebrado un contrato con una agencia publicitaria, por el que -a cambio de una remuneración - se obligaba a grabar un video publicitario, y aceptaba que este fuese exhibido en televisión por un tiempo determinado. La empresa que había encargado la publicidad sobrepasó el tiempo pactado para su difusión pública, circunstancia que motivó que se acogiese el recurso, prohibiéndose la exhibición de las imágenes (no obstante, por considerarse vulnerado el derecho de propiedad de la recurrente).

c) Aunque la autorización fue uno de los elementos de juicio que se invocaron por el Tribunal ${ }^{30}$ para rechazar un recurso de protección en el caso Cavieres Logan con Corporación de Televisión de la Pontificia Universidad Católica de Chile y otros ${ }^{31}$, y no el único, es destacable por tratarse de un supuesto en el que se resolvió que es posible autorizar la captación y difusión de imágenes. En los hechos, el recurrente en su oportunidad autorizó el empleo de su imagen en un reportaje televisivo acerca de violencia doméstica, para luego oponerse a que se reiterase su divulgación, circunstancia que no habría sido suficiente por sí sola para que se acogiese el recurso (de paso, se privó de valor a la revocación de la autorización).

d) En el caso Bustamante con Editorial Televisa Chile S.A. ${ }^{32}$, el juicio fue promovido por un modelo profesional que ejerció una acción por responsabilidad extracontractual contra una editorial, por la inclusión de fotografías con su imagen en un artículo concerniente a la eyaculación precoz. Sin perjuicio del contenido específico de la pretensión del demandante (solicitó -y obtuvo- ${ }^{33}$ una indemnización de perjuicios por daño moral, derivado de las molestias y alteraciones psicológicas que sufrió), en los hechos se había autorizado la captación y difusión de las imágenes por medio de un contrato (en primera instancia se rechazó la demanda por ese motivo), pero con una finalidad evidentemente diferente a la que luego le imprimió el cesionario de las imágenes. En definitiva, el caso fija adecuadamente una regla que se suele repetir por la doctrina ${ }^{34}$ en esta materia: la autorización debe

${ }^{29}$ Resuelto por la Corte de Apelaciones de Santiago el 12 de agosto de 1997, y confirmado por la Corte Suprema el 9 de septiembre del mismo año (Gaceta Jurídica, no 207, 1997, pp. 57-60).

${ }^{30}$ Se consideró que había una suerte de interés informativo, y además, que el recurrido se allanó al recurso.

${ }^{31}$ Resuelto por la Corte Suprema, el 15 de enero de 2002.

32 Sentencia de la Corte Suprema del 10 de octubre de 2006.

${ }^{33}$ La indemnización se fijó en 3 millones de pesos.

${ }^{34}$ Por ejemplo, Le Tourneau, P. Droit de la responsabilité et des contrats. Régimes d'Indemnisation, Dalloz, Paris, 2014, p. 681 
ser específica, y solo implica que las imágenes pueden ser utilizadas con el objeto para el que fueron ofrecidas o solicitadas, y no otro ${ }^{35}$.

e) En el caso Salazar Leiva con Ministerio de Obras Públicas ${ }^{36}$ se entendió -reprochablemente- que la autorización para usar la imagen de una persona podía ser incluso presunta. La Corte Suprema resolvió (revocando -con voto disidente- el fallo de primera instancia) rechazar un recurso de protección interpuesto por un particular cuya imagen había sido incluida en un letrero que promocionaba obras del Ministerio recurrido. Uno de los principales fundamentos de la decisión fue que el recurrente se habría percatado cuando era fotografiado al lado de una calle, mientras esperaba transporte público, sin presentar oposición a la captación. De esos hechos el Tribunal entendió que se desprendía el consentimiento del fotografiado, en una decisión bastante discutible (implicaría que cada vez que alguien es fotografiado y no se opone explícitamente a ello, es porque lo autoriza).

f) El caso Guiloff con Red Televisiva Megavisión S.A. ${ }^{37}$ constituye un buen ejemplo de un problema de autorización para captar una imagen, resuelto de una mala manera. En los hechos, un sujeto que se encontraba en Sudáfrica presenciando el Campeonato Mundial de Fútbol el año 2010, tras asistir a un partido, concurrió a un bar que tenía publicidad de una conocida marca de cervezas chilena. Una vez dentro, una persona le preguntó si tenía algún inconveniente en compartir con "promotoras" de la marca de cerveza, y que ello quedase registrado fotográficamente, con el objeto de incluir las imágenes en el registro interno de la empresa (el recurrente era uno de los pocos chilenos presentes en el local, y además vestía la camiseta de la selección nacional de fútbol $)^{38}$. Al poco tiempo se enteró que la empresa recurrida había difundido sus imágenes por internet, y además, que habían

35 Como otros ejemplos prácticos de esta regla, se pueden citar: El caso Larraín Fuenzalida y otra con Consejo Nacional para el Control de Estupefacientes (resuelto por la Corte Suprema, el 25 de noviembre de 2004 [véase Revista Fallos del Mes n ${ }^{\circ}$ 528, 2004, p. 2.877]). Recayó en un recurso de protección presentado por la madre de una menor, cuya imagen había sido incluida sin autorización en un calendario alusivo a una campaña antidrogas. Originalmente se había prestado la autorización para la captación y difusión de la imagen, pero en otro medio, y para servir de accesorio a un reportaje sobre una materia absolutamente distinta, circunstancia que motivó que se acogiese el recurso; el caso Yánéz con Distribuidora Importadora Laibe (véase n. 100), en el que la Corte Suprema señaló expresamente que la autorización para captar la imagen no implica una renuncia de la disponibilidad sobre la misma por parte de su titular, traducida en una autorización tácita para su utilización por parte de terceros; y el caso Valdivia Jara con Goic Simunovic y otro (resuelto por la Corte Suprema, el 10 de marzo de 2015). En la sentencia se concedió una indemnización de 10 millones de pesos a una mujer que se desempeñaba como bailarina en un club nocturno, que si bien había autorizado a los administradores del local para captar fotografías y videos de sus actuaciones, no lo había hecho expresamente para que estas fuesen difundidas. En los hechos, los demandados divulgaron las grabaciones en la página web del local, circunstancia que configuró el uso no autorizado de la imagen.

${ }^{36}$ Resuelto por la Corte Suprema, el 7 de diciembre de 2009.

${ }^{37}$ Sentencia de la Corte de Apelaciones de Santiago, del 22 de junio de 2011, confirmada por la Corte Suprema el 16 de agosto del mismo año.

${ }^{38}$ El recurrente, que se dedicaba a la producción de eventos y a las relaciones públicas, estaba al tanto de ese tipo de prácticas y entendía que las imágenes no serían exhibidas públicamente, y menos por medios de comunicación masivos. 
sido exhibidas en un programa televisivo nocturno relativo a variedades, e incluso en el periódico Las Últimas Noticias, acompañadas del titular el eterno carrete de los chilenos en las noches de Sudáfrica. En los fundamentos del recurso se alegó la difusión no autorizada de las imágenes, y además que por medio de estas se asociaba al recurrente en forma errónea y "negativa" a una bebida alcohólica, circunstancia que también lesionaba su reputación, considerando sobre todo el rubro en el que se desempeñaba profesionalmente. Al resolver el recurso, la Corte enfrentó el problema como una hipótesis de colusión entre los derechos consagrados en el artículo 19 número 4 de la Constitución (vida privada y a la honra), y la libertad de informar de los recurridos, específicamente referida a poner en conocimiento de la ciudadanía de un evento deportivo como lo era el Mundial de Fútbol, que en esos días se llevaba a efecto en Sudáfrica, en el que participaba la selección nacional de nuestro país ${ }^{39}$. En ese contexto, el Tribunal argumentó que solo se trataba de notas periodísticas y reportajes, dirigidos exclusivamente a informar de manera fidedigna los sucesos relacionados con el evento deportivo, con particular énfasis en el hecho de que la difusión no había tenido una finalidad publicitaria. Agregó que el recurrente había concurrido voluntariamente al recinto donde se captaron las imágenes, y que no podía menos que saber que estas serían captadas con una finalidad exclusivamente informativa, agregando que en ese orden no se había afectado ni la honra ni el derecho de propiedad del afectado. Como se puede intuir, en este caso se autorizó la captación de las imágenes, mas no su difusión, y a la postre esta circunstancia ni siquiera fue considerada por el Tribunal: invocó el interés público (mediante el derecho a la información), respecto de un contenido discutiblemente relevante, e insinuó la existencia de una autorización tácita (o incluso presunta) para la difusión (que a juzgar por los dichos del recurrente, no concurrió).

g) Otra decisión llamativa recayó en el caso Pakomio Higgs con Hüber Mardones y otros ${ }^{40}$. Se acogió un recurso de casación contra el fallo de la Corte de Santiago, que había rechazado una demanda de indemnización de perjuicios por responsabilidad extracontractual interpuesta por una mujer que oficiando de modelo había aceptado ser retratada por un fotógrafo profesional en las afueras de un hotel de Isla de Pascua. Supuestamente prestó su autorización solo con ese objeto, pese a que luego las imágenes fueron utilizadas con distintos fines, y principalmente en propaganda gráfica de una aerolínea, en diversos medios. La Corte de Apelaciones había fundado el rechazo de la demanda en que como la demandante había prestado su autorización para la captación, el uso posterior de la imagen para fines comerciales no era un delito ni cuasidelito civil, sino que una conducta cuyas consecuencias deberían haberse resuelto por medio de una acción diferente. La Suprema resolvió acoger la demanda contra el fotógrafo, liberando a las empresas codemandadas que habían participado en los contratos de distribución, publicidad, o que se

\footnotetext{
${ }^{39}$ Considerando $4^{\circ}$.

${ }^{40}$ Sentencia de la Corte Suprema, de fecha 11 de agosto de 2011.
} 
habían beneficiado con el uso de las imágenes. Hizo suyos los razonamientos del Tribunal de $1^{a}$ instancia, que había acogido la demanda fundando su decisión en que la conducta de las demandadas había vulnerado los derechos contemplados en los números 4 y 24 del artículo 19 de la Constitución, con lo que se cumplían los requisitos de la responsabilidad extracontractual. Se trata de otro supuesto en el que el Tribunal exige que se respete el tenor (presunto incluso) de la autorización prestada, en el sentido de que sería siempre específica, esto es, solo para los fines para los cuales fue prestada originalmente.

h) Merece citarlo también el caso Claude Reyes con Producciones y Talleres La Toma Limitada ${ }^{41}$, en el que se rechazó un recurso de protección presentado por un entonces candidato presidencial, invocando su derecho a la imagen, que habría sido supuestamente vulnerado por la difusión en internet, de un video en el que se le denostaba públicamente. En los hechos, se trataba de imágenes que habían sido editadas por la misma empresa a la que el recurrente encargó la realización de su campaña política - habían sido captadas no solo con su autorización, sino que a su expresa solicitud-, pero con leyendas en las que se reprochaba ácidamente al candidato, el incumplimiento de obligaciones contractuales para con la recurrida. Uno de los principales argumentos para rechazar el recurso fue que las imágenes se habían cedido voluntariamente por el recurrente. Sin embargo, debe tenerse presente que si bien la empresa recurrida había sido autorizada para usarlas con un destino específico (crear propaganda política), este claramente no se respetó (a favor del Tribunal, se puede acotar que en la resolución del recurso, la autorización fue un argumento casi de carácter tangencial $)^{42}$.

i) Es relevante a estos efectos también la sentencia ${ }^{43}$ que resolvió el caso Bertero Hola con Comercial Eccsa S.A. Recayó en un juicio iniciado por una demanda de indemnización de perjuicios por responsabilidad extracontractual interpuesta por dos mujeres que habían sido, durante 13 años, las figuras principales de la campaña publicitaria de una conocida multitienda, supuestamente sin autorización. Sin perjuicio de ciertos detalles llamativos del juicio ${ }^{44}$, la discusión respecto a si el empleo de las imágenes se había autorizado originalmente o no, se diluyó en sede casacional, donde se resolvió rechazar la demanda por considerarse prescrita la acción (pese a que la campaña publicitaria se había exhibido hasta la época de la presentación de la demanda). El Tribunal razonó que como las demandantes

${ }^{41}$ Resuelto por la Corte de Santiago, el 24 de febrero de 2014 (sentencia confirmada por la Corte Suprema, el 18 de marzo de 2014).

${ }^{42}$ Se insistió en el carácter de persona pública del recurrente (lo que podría ser relevante en materia de derecho a la vida privada o de derecho a la imagen, pero no en el caso del derecho al honor, el que no se invocó en el recurso).

43 De fecha 12 de octubre del 2012.

${ }^{44}$ Por ejemplo, que en las instancias se acogió la demanda, fijándose la indemnización en la suma de 100 millones de pesos (véase la sentencia de la Corte de Santiago del 24 de agosto de 2010, que confirmó la de primera instancia). 
habrían fundado su reproche en que la demandada no había advertido la inexistencia de su voluntad para ser objeto de la publicidad, el plazo de prescripción para accionar había comenzado a correr el año 1997, ya que en ese año le habían comunicado expresamente a la demandada su intención de que las imágenes no se siguiesen exhibiendo. Si bien puede tratarse de un caso en el que se le concede valor a la revocación de una autorización para usar imágenes - pues a partir de ese hecho el Tribunal fijó el inicio del cómputo del plazo de prescripción de la acción-, en la práctica deja bastantes dudas, ya que pese a esta supuesta revocación (que derivó en negociaciones que fracasaron), la demandada siguió utilizando la campaña publicitaria.

j) Por último, en el caso Valderrama con Jerez ${ }^{45}$, se resolvió favorablemente un recurso de protección interpuesto por un sujeto cuya imagen (específicamente, la fotografía que se inserta en la cédula de identidad) fue "subida" a una red social sin autorización del recurrente ${ }^{46}$. En esta oportunidad, la Corte Suprema razonó que la autorización de la persona retratada es indispensable para utilizar su imagen.

\section{La legislación}

Ahora bien, sin perjuicio de que no existe una regulación general sobre el derecho a la imagen, ni tampoco una prohibición expresa que impida una autorización para el ejercicio por un tercero ${ }^{47}$, sí es posible identificar normas que se refieren expresa o tácitamente a actos de autorización y cesión de imágenes de personas, y que permitirían afirmar que la celebración de actos y contratos sobre el derecho a la imagen es legalmente admitida en nuestro país. En ese orden, los principales respaldos normativos son los siguientes:

a) En primer lugar, es posible invocar como respaldo legal a favor de la disponibilidad del derecho a la imagen el artículo 20 letra c) de la Ley $\mathrm{N}^{\circ} 19.039^{48}$, que prohíbe registrar como marcas El nombre, el seudónimo o el retrato de una persona natural cualquiera, salvo consentimiento dado por ella o por sus herederos, si bubiera fallecido. Sin embargo, serán susceptibles de registrarse los nombres de personajes históricos cuando hubieran transcurrido, a lo menos, 50 años de su muerte, siempre que no afecte su honor. En ese orden, la norma autoriza registrar como marcas imágenes (retratos) de personas en la medida en que el sujeto retratado haya prestado su consentimiento. Pese a que la ley emplea esta última expresión, pareciera referirse en realidad a un

${ }^{45}$ Resuelto por la Corte Suprema el 14 de septiembre de 2015 (se revocó la sentencia de la Corte de Apelaciones de Punta Arenas, de fecha 19 de mayo de 2015).

${ }^{46}$ Aunque no es relevante a estos efectos, debe tenerse presente que la fotografía se subió con el objeto de denigrar al recurrente, públicamente.

${ }^{47}$ Como sí ocurre por ejemplo, en materia de propiedad intelectual, a propósito del llamado "derecho moral de autor". El artículo 16 de la Ley 17.336 señala que Los derechos numerados en los artículos precedentes son inalienables y es nulo cualquier pacto en contrario.

${ }^{48}$ Ley de Propiedad Industrial. 
acto unilateral autorizante, sin que sea indispensable un acuerdo de voluntades con el sujeto que registra la marca (indica dado por $)^{49}$. No obstante, por la materia regulada en la ley -propiamente patrimonial y vinculada a objetos comerciablesprobablemente en la práctica se configuren relaciones contractuales. La norma incluso resuelve la situación del titular fallecido, entregándole el poder de disposición a sus herederos, a menos que se trate de "personajes históricos", caso en el que no sería necesario obtener la autorización si ha transcurrido el plazo indicado, desde la muerte del sujeto.

b) También aporta información relevante el artículo 5 de la Ley $\mathrm{N}^{\mathrm{o}} 20.584^{50}$, que establece los derechos de las personas que reciben prestaciones de salud, y como contrapartida las obligaciones de los prestadores. Entre estas, les exige en su letra c) Respetar y proteger la vida privada y la honra de la persona durante su atención de salud. En especial, se deberá asegurar estos derechos en relación con la toma de fotografías, grabaciones o filmaciones, cualquiera que sea su fin o uso. En todo caso, para la toma de fotografías, grabaciones ofilmaciones para usos o fines periodísticos o publicitarios se requerirá autorización escrita del paciente o de su representante legal. La norma contempla la posibilidad de emplear imágenes ajenas con la autorización (escrita, por cierto) del fotografiado, incluso para actividades vinculadas con la publicidad, circunstancia que merece ser destacada. Para estos efectos, una simple autorización viene a legitimar el uso de la imagen de un tercero, quien que por ese acto, en ejercicio de su derecho a la imagen, renuncia a accionar invocando los remedios que le concede el ordenamiento para proteger los derechos fundamentales ${ }^{51}$.

c) En tercer lugar, aunque parece más forzado, quizás podría invocarse también para justificar la legitimidad de la disposición del derecho a la imagen de un sujeto, el artículo 1.466 del Código Civil, interpretado a contrario. Prescribe que adolece de objeto ilícito, la venta de -entre otras cosas-láminas, pinturas y estatuas obscenas, regla que implicaría que la comercialización de esas mismas cosas, cuando no son calificables como obscenas, es lícita. Aunque no se desprende del tenor literal del artículo, la lógica induce a pensar que esas láminas, pinturas y estatuas, deben contener (salvo hipótesis un tanto rebuscadas) imágenes o representaciones de seres humanos. Si bien se refiere a la venta del "soporte físico" donde estarían contenidas las imágenes, es evidente que se hace cargo además de la legitimidad

${ }^{49}$ En todo caso, existen otros escenarios similares en los que el legislador ha empleado la expresión autorización en sentido amplio, incluyendo mecánicas contractuales, e incluso considerándola como una figura análoga. Un ejemplo de esto se puede encontrar en el inciso $1^{\circ}$ del artículo 20 de la Ley $\mathrm{N}^{\circ} 17.366$ (Propiedad Intelectual): Se entiende por autorización el permiso otorgado por el titular del derecho de autor, en cualquier forma contractual, para utilizar la obra de alguno de los modos y por alguno de los medios que esta ley establece.

${ }^{50}$ Denominada ley que Regula los Derechos y Deberes Que Tienen las Personas en Relación con Acciones Vinculadas a su Atención en Salud.

${ }^{51}$ La Corte de Apelaciones de Santiago, el 17 de noviembre de 1992 (sentencia confirmada por la Corte Suprema el 16 de diciembre de 1992, véase Gaceta Jurídica n 150, 1992, p. 42), acogió un recurso de protección interpuesto por el hijo de una mujer que se había sometido a exámenes médicos invasivos, que fueron filmados sin autorización de la paciente. 
de la disposición de la imagen misma de la persona incorporada en el soporte. En caso contrario, si se entendiese que la imagen de una persona es indisponible, el artículo -así interpretado, al menos- sería irrelevante e innecesario.

d) Y por último ${ }^{52}$, quizás el fundamento normativo más notable: los artículos 145 I y 152 bis F del Código del Trabajo, que regulan el empleo de imágenes de artistas y deportistas profesionales, respectivamente, en el marco del Derecho Laboral. El artículo 145 I dispone que el uso y explotación comercial de la imagen de los trabajadores de artes y espectáculos, para fines distintos al objeto principal de la prestación de servicios, por parte de sus empleadores, requerirá de su autorización expresa. En cuanto a los beneficios pecuniarios para el trabajador, se estará a lo que se determine en el contrato individual o instrumento colectivo, según corresponda. Y el artículo 152 bis F contiene una regla análoga, con un pequeño matiz, debido a que la autorización expresa -para fines distintos al objeto principal de la prestación de servicios- debe ser además específica, ya que se exige para cada ocasión en que la imagen sea utilizada ${ }^{53}$. Ambas normas, además de su evidente aporte en materia de relaciones laborales en rubros sensibles a problemas de derecho a la imagen, aportan elementos relevantes a la discusión.

Debe destacarse, en primer lugar, que el legislador distinguió el uso de la explotación de la imagen del sujeto, entendiendo aparentemente por el primero un ejercicio sin finalidad lucrativa, y por el segundo lo contrario ${ }^{54}$. Y en segundo lugar, incorporan expresamente a nuestro ordenamiento la admisibilidad de realizar negocios jurídicos

52 Las normas señaladas en el texto principal no serían las únicas, pero sí las más llamativas. Entre otras, aunque de una utilidad aparentemente menor, se puede mencionar el artículo 66 de la Ley $\mathrm{N}^{\circ} 17.336$, relativo a las autorizaciones que se exigen para la grabación, reproducción, transmisión o retransmisión de las interpretaciones y ejecuciones de los artistas. En este caso, el bien jurídico tutelado sería la obra del sujeto (y no su identidad o imagen, al menos directamente), y además, está dirigida a interpretaciones que no necesariamente incluyen imágenes (dependiendo de la disciplina artística, puede que las incorporen o no), con lo que su relevancia en esta parte sería menor.

${ }^{53}$ El texto de la norma es El uso y explotación comercial de la imagen de los deportistas profesionales y de los trabajadores que desempeñan actividades conexas, por parte de sus empleadores, para fines distintos al objeto principal de la prestación de servicios, y en cada caso en que esta deba ser utilizada, requerirá de su autorización expresa. En cuanto a los beneficios pecuniarios para el trabajador, se estará a lo que se determine en el contrato individual o instrumento colectivo, según corresponda. Es importante señalar que el art. 145 I fue incorporado al Código del Trabajo en la Ley $\mathrm{N}^{\circ} 19.889$, publicada en el Diario Oficial el 24 de septiembre de 2003, y que el 152 bis $\mathrm{F}$ es posterior (corresponde a una modificación contenida en la Ley $\mathrm{N}^{\circ} 20.178$, publicada en el Diario Oficial el 25 de abril de 2007). En los antecedentes de la historia de la Ley $\mathrm{N}^{\circ} 19.889$, las discusiones relativas a esta norma se centraron en la necesidad de proteger la dignidad de los trabajadores (y su patrimonio), y al menos en un punto del debate parlamentario la vinculan con la propiedad intelectual. En la historia de la Ley $\mathrm{N}^{\circ} 20.178 \mathrm{el}$ panorama no es muy distinto en relación con la admisibilidad de la disposición de imágenes -como siempre, se da por establecida-, sin perjuicio de que se puede observar una mayor discusión respecto de la necesidad de incorporar esta materia en el Código del Trabajo (se alude insistentemente a que la norma se refiere al "valor comercial" de las imágenes). La resistencia se debió principalmente a que la comercialización de lo que se conoce como "derechos de imagen" de los futbolistas profesionales es un activo en algunos casos de un valor respetable.

${ }^{54}$ Entendiéndose para estos efectos que finalidad lucrativa sería análoga a cualquier uso comercial. Es cierto que uso comercial y publicitario no son análogos, siendo el primero el género, y el segundo la especie 
sobre imágenes de personas físicas, estableciendo incluso un régimen de autorización implícita en los contratos de trabajo de los trabajadores de artes y espectáculos y de los deportistas profesionales, cuando el uso de las imágenes es para fines análogos al objeto principal de la prestación de servicios. Si bien la finalidad de ambos artículos apunta a evitar eventuales conflictos generados por una posible resistencia de artistas o deportistas a que su trabajo no sea difundido por medios audiovisuales, circunstancia que en muchos casos conduciría en que simplemente no se pudiese desempeñar la labor contratada (conduciría a situaciones absurdas, como la de un actor de teleseries que se negase a aparecer en televisión), la autorización no es óbice a que el trabajador tenga derecho a percibir la correspondiente contraprestación pecuniaria derivada de la explotación de su imagen (la que, probablemente, se negociará caso a caso).

Queda de esta forma plasmado un régimen dispositivo sobre el derecho a la imagen, que si bien es especial para el Derecho del Trabajo, implica un reconocimiento rotundo por parte del legislador de la posibilidad de que se pueda ceder a un tercero el derecho a explotar la imagen de una persona (y por tanto renunciar a la facultad de hacerlo por sí mismo), al menos en ámbitos específicos y bajo condiciones claramente predeterminadas.

\section{FORMA Y ALCANCE DE LA MANIFESTACIÓN DE VOLUNTAD}

Existe cierto consenso en doctrina de que el acto autorizante (incorporado o no en una relación contractual) puede ser manifestado en forma expresa o tácita ${ }^{55}$ (por ejemplo, posar ante un fotógrafo). Nuestra legislación, por su parte, exige en algunas de las normas señaladas precedentemente que la voluntad se manifieste en forma "expresa", y en algunos casos incluso por escrito, reglas que se podrían interpretar en el sentido de que en otros supuestos no regulados (la regla general) esta no debe revestir formas especiales, y puede ser tácita. La jurisprudencia reseñada contiene hipótesis de autorizaciones tácitas (según el contexto, interpreta incluso una aquiescencia a la captación, como extensiva tácitamente a la divulgación) ${ }^{56}$, de modo que al menos en el contexto nacional no habría inconvenientes en aceptarla como regla general ${ }^{57}$.

Por otra parte, pese a que hay al menos un precedente claro en el que el Tribunal admitió una supuesta voluntad "presunta" 58 , no parece deseable en esta materia que se interpreten ciertas conductas de las personas a ese extremo ${ }^{59}$. Se trata de un derecho

(habría usos "comerciales" ajenos al ámbito de la publicidad, como el del cine por ejemplo, y cualquier otra actividad en la que se persiga lucro, no vinculada directamente al ámbito publicitario).

${ }^{55}$ En este sentido, Barros (n. 34) p. 564; Corral (n. 15) p. 166; y Peña (n. 15) p. 297 (quien en todo caso aconseja una manifestación que conste por escrito, para efectos probatorios).

${ }^{56}$ Es lo que se resolvió por ejemplo, en Guiloff con Red Televisiva Megavisión S.A. (III.1.- letra f)).

57 Aunque en el caso de los incapaces, no parece adecuado permitir autorizaciones tácitas.

58 Véase Salazar Leiva con Ministerio de Obras Públicas (III.1.- letra e)).

59 En este sentido, entre otros, Bertrand, A. Droit à la vie privée et droit à l'image, Litec, Paris, 1999, p. 175; y Ollard (n. 20) p. 353. 
personalísimo que se vincula directamente con la dignidad humana, y que por tanto requiere un tratamiento acorde a su naturaleza, que implica la exigencia indubitada de que el titular del derecho ha autorizado a un tercero para utilizar su imagen. Por este motivo, además, la autorización debe ser siempre interpretada en forma restrictiva ${ }^{60}$, y como atingente solo a la finalidad o finalidades específicas para las que fue prestada.

\section{La ReVOCACióN}

El aludido carácter de irrenunciable e indisponible de los derechos de la personalidad, y que se atribuye usualmente al derecho a la imagen, ha inducido además a que se defienda la revocabilidad de la autorización prestada a un tercero (cuya razón de ser es de índole moral o personalísima, ya que se trata de un acto que afecta directamente intereses de la esfera personal del sujeto ${ }^{61}$. Al respecto, si bien la doctrina en forma mayoritaria entiende que la revocación es procedente ${ }^{62}$, es posible observar posiciones diferentes según el contexto en que se prestó la autorización, y en su caso, a las consecuencias que esta puede acarrear.

Al respecto, habrían al menos dos lecturas: una, entender que se debe distinguir si se trató de un acto unilateral de autorización o de un contrato entre el titular del derecho y el sujeto que explotará su imagen (que por regla general será oneroso). En este supuesto, en el primer caso la autorización prestada sería revocable en cualquier tiempo, mas en el segundo no ${ }^{63}$ (al menos, no a todo evento). Y la segunda lectura, que no distingue la naturaleza del acto autorizante (contractual o no), y que defiende la revocación de la autorización para usar la imagen, en cualquier tiempo y sin expresión de causa, sin perjuicio de la eventual obligación de indemnizar los perjuicios que aquella le cause al sujeto originalmente autorizado ${ }^{64}$. En España el legislador se refirió a esta cuestión en una norma que ha sido objeto de diversas interpretaciones ${ }^{65}$. Para algunos, solo habría

${ }^{60}$ Bertrand (n 69) p. 175 ; Corral (n. 15) p. 167; Goubeaux (n. 23) p. 302 ; Igartua (n. 1) pp. 324325 , sobre todo cuando se otorga para una utilización comercial.

${ }^{61}$ Rodríguez (n. 32) p. 869.

${ }^{62}$ En contra, Masson, J. "Le droit à l'image”, en Renchon, J.L., Les droits de la personnalité, Bruylant, Bruselas, 2009, p. 238. Justifica defender la "irrevocabilidad” en que el derecho a la imagen, a su juicio, es absolutamente disponible.

${ }^{63}$ En este sentido por ejemplo, Prosser W. "Privacy", en California Law Review, vol. 48, 1960, p. 420.

${ }^{64}$ En este sentido, entre otros, Agate (n. 26) pp. 567-568, quien entiende que en el caso del contrato, para justificar la procedencia de la revocación, se debe disociar esta del acto que genera el vínculo contractual; Galgano (n. 11) p. 181, quien previene que si la revocación del consentimiento fue injustificada y caprichosa, deberá indemnizarse el daño al otro contratante, por abuso del derecho de la personalidad; Le Tourneau (n. 43) pp. 681-682.

${ }^{65}$ El artículo $2^{\circ}$ de la Ley Orgánica $1 / 1982$ dispone: Uno. La protección civil del honor, de la intimidad y de la propia imagen quedará delimitada por las leyes y por los usos sociales atendiendo al ámbito que, por sus propios actos, mantenga cada persona reservado para sí misma o su familia. Dos. No se apreciará la existencia de intromisión ilegítima en el ámbito protegido cuando estuviere expresamente autorizada por ley o cuando el titular del derecho bubiese otorgado al efecto su consentimiento expreso. Tres. El consentimiento a que se refiere el párrafo anterior será revocable 
regulado el acto unilateral, permitiendo su revocación a todo evento (con indemnización de perjuicios) y guardó silencio frente a una eventual cesión o autorización contractual, lo que dejó abierta la posibilidad de admitir o no la revocación del consentimiento ${ }^{66}$, pero actualmente sumaría más adeptos la tesis contraria, que interpreta la norma en el sentido de extender la facultad de revocar al plano contractual (y con fundamentos más convincentes) ${ }^{67}$.

En la doctrina nacional, primaría la idea de que el acto unilateral es siempre revocable $^{68}$ (al menos en cuanto a sus efectos futuros) ${ }^{69}$, a menos que la autorización se haya prestado en el marco de un contrato, caso en el que no se podría revocar ${ }^{70}$. La solución más razonable parece ser esta, considerando que equilibra dos intereses dignos de una protección análoga: la naturaleza de los derechos de la personalidad, y el pacta sunt servanda ${ }^{71}$. En otras palabras, la declaración de voluntad por la que el sujeto autoriza a un tercero a utilizar su imagen, es siempre revocable por formar parte de un derecho que es en esencia irrenunciable, y el o los destinatarios de esa manifestación de voluntad debieran considerar esa circunstancia dentro de sus expectativas al interpretar la autorización ${ }^{72}$.

en cualquier momento, pero habrán de indemnizarse en su caso, los daños y perjuicios causados, incluyendo en ellos las expectativas justificadas.

${ }^{66}$ Hay quienes entienden que la norma debe interpretarse restrictivamente, en el sentido de que no se refiere a autorizaciones contractuales, motivo por el que si se ceden contractualmente una o más facultades del derecho, no cabría la revocación indicada, véase Clavería (n. 16), pp. 50-51. En sentido similar también, De Verda (n. 17), p. 79, quien recalca que es innecesaria una expresión de causa, ni que proceda una eventual pretensión indemnizatoria del autorizado original (en abstracto, sin considerar la norma española).

${ }^{67}$ Martín entiende que la norma de la Ley Orgánica 1/1982 no distingue entre acto unilateral y contrato, siendo en consecuencia siempre revocable la autorización (Martín, A. "El contenido patrimonial del derecho a la propia imagen”, en Revista de Derecho Mercantil, $\mathrm{n}^{\circ} 242,2001$, p. 1.742). En el mismo sentido, Rodríguez (n. 32) pp. 868 y sgtes; y Vendrell (n. 8) p. 368 y p. 394.

${ }^{68}$ Barros (n. 34) p. 565; Nogueira (n. 10) p. 272.

${ }^{69}$ Corral (n. 15) p. 175.

${ }^{70}$ Véase Barros (n. 34) p. 565. Hay al menos una sentencia en este sentido, véase el caso Salazar con Diario La Tercera de La Hora (III.1.- letra a)). Queda la duda respecto de la revocación de una autorización inserta en un contrato, cuando el uso de la imagen deviene en una vulneración de otro derecho fundamental del sujeto (por ejemplo, el honor), producto de un cambio de las circunstancias de hecho que justificaron originalmente la celebración del contrato (a diferencia de lo que se postula a propósito de la teoría de la imprevisión -que a fin de cuentas pasa por una revisión judicial-, aquí el cumplimiento de la obligación no se torna más onerosa, sino que potencialmente le puede causar un perjuicio a una de las partes). En principio, pareciera razonable aceptar en ese escenario la procedencia de una revocación, debidamente justificada en la protección de la dignidad del sujeto.

${ }^{71}$ En nuestro Derecho positivo hay ejemplos de revocabilidad de autorizaciones prestadas a propósito de derechos subjetivos calificables de "personalísimos". El artículo 146 del Código Sanitario, a propósito del derecho de toda persona a disponer de su cadáver, con el objeto de ser usado para fines de investigación o terapéuticos, dispone que la autorización es siempre revocable (por escrito); y el artículo 4 de la Ley de Protección De Datos De Carácter Personal ( ${ }^{\circ}$ 19.628), a propósito del consentimiento prestado para el tratamiento de datos personales, regula expresamente que la autorización puede ser revocada, aunque sin efecto retroactivo.

${ }^{72}$ Reconociendo en todo caso que entre nosotros hay al menos un precedente de los señalados, en el que la Corte Suprema resolvió en sentido contrario, rechazando la validez de una revocación (véase III.1.c)). 
Pero si esa declaración se ha realizado en un contrato, en el que existen intereses contrapuestos que son susceptibles de inspirar protección legal, lo razonable es entender que el estatuto contractual amerita ser respetado y en consecuencia considerarse a la revocación como un incumplimiento contractual ${ }^{73}$. Ahora, en el evento de una revocación a una autorización unilateral, esta sería oponible a todos, incluso a eventuales cesionarios (el derecho no se ha transferido, sino que solo se ha autorizado el uso de la imagen, por un acto de autonomía privada $)^{74}$. Queda planteada la duda respecto de la posibilidad de que el sujeto originalmente autorizado solicite que se le indemnicen los perjuicios que le podría haber causado la revocación. En principio, si se acepta la procedencia de la revocación en términos generales, por las particulares características del derecho cuya facultad se cedió inicialmente, se ve difícil de justificar la procedencia de una acción indemnizatoria sin una norma que la respalde (a menos que se cumplan en el caso concreto los requisitos de la Responsabilidad Civil) ${ }^{75}$. En otras palabras, atendido el contexto normativo nacional vigente, perece contradictorio aceptar que el sujeto puede revocar su autorización, y a la vez imponerle la obligación de indemnizar los perjuicios que cause con dicha revocación (atendido que no se trataría de un acto ilícito) ${ }^{76}$.

\section{LEgITIMACIÓN: LOS MENORES}

Cuando el titular del derecho a la imagen es incapaz, y sobre todo cuando se trata de un infante o de un menor ${ }^{77}$, surgen fundadas aprehensiones respecto de la legitimación para prestar la autorización ${ }^{78}$. Esto, considerando que es usual encontrar en la publicidad anuncios en los que se muestran menores (e incluso a neonatos), y que

${ }^{73}$ Sobre todo si se trata de un contrato de ejecución instantánea, la conclusión podría ser otra, en los contratos con obligaciones de ejecución duradera indefinida, caso en el que se suele razonar que es admisible la extinción unilateral del contrato, atendido que en caso contrario se afecta la libertad del obligado (Peñailillo, Daniel. Obligaciones, Editorial Jurídica de Chile, Santiago, 2003, p. 349).

${ }^{74}$ De Verda (n. 17), p. 83. Vendrell explica este fenómeno en que una vez ejercitada válidamente la facultad revocatoria o extintiva, el titular recuperaría automáticamente la plena titularidad sobre el objeto previamente transmitido (Vendrell [n. 8] p. 387).

${ }^{75}$ Como se señaló en el texto, el legislador español estableció expresamente la obligación de indemnizar (véase n. 75) en el evento de una revocación (centrándose las dudas de la doctrina en si esa revocación es admisible o no cuando la autorización está contenida en un contrato). En la doctrina nacional se manifiestan a favor de la obligación de indemnizar los perjuicios que la revocación hubiese causado a terceros: Barros (n. 34), p. 565 y Nogueira (n. 10), p. 272.

${ }^{76}$ A menos que se funde, por ejemplo, en una suerte de "abuso de derecho", pero eso ya requiere la concurrencia de otros requisitos, no en la revocación por sí sola (y es a su vez discutible).

${ }^{77}$ Para un interesante trabajo sobre la protección de la imagen de menores, véase Lathrop G., Fabiola. "El derecho a la imagen de niños, niñas y adolescentes en Chile”, en Revista Chilena de Derecho, vol. 40, n 3, 2013.

${ }^{78}$ Este problema, por su complejidad, amerita un trabajo independiente por sí solo, motivo por el que en esta ocasión solo se exponen cuestiones generales (como temas pendientes se pueden señalar, entre otros: el derecho del niño a ser oído y a que su opinión sea debidamente tomada en cuenta en todos los asuntos que puedan afectar su proyecto de vida; y los problemas que se pueden presentar ante discrepancias entre el padre y la madre respecto de este tema, cuando la patria potestad la ejerzan ambos). 
es discutible que en materia de derechos de la personalidad sea suficiente con recurrir simplemente a la representación legal, prescindiendo de la opinión del titular efectivo (cuando puede prestarla). La relación inherente del derecho subjetivo con la dignidad humana sugieren una cautela superior a la que se emplea actualmente por el legislador, respecto de la representación de incapaces en general. Hay ordenamientos en los que se ha regulado expresamente esta cuestión, estableciendo controles más estrictos que los usuales en materia de actos que afectan a incapaces, y a su vez se les concede una injerencia superior al titular, permitiéndoseles incluso obrar por sí mismos ${ }^{79}$. En nuestro país, ante el silencio del legislador ${ }^{80}$, la doctrina ha entendido que la autorización correspondería al representante legal ${ }^{81}$, cuidando que si el acto repercute "en el interés superior del menor", no debiera permitirse la autorización ${ }^{82}$. Hay al menos una propuesta que pretende complementar las normas acerca de la protección del menor del Código Civil y de la Convención sobre Derechos del Niño, con las que regulan la capacidad de los menores en materia de Derecho Laboral ${ }^{83}$. Específicamente se trata del artículo 13 inciso $2^{\circ}$ del Código del Trabajo, que permite celebrar contratos a los menores de 18 años y mayores de 15, con autorización de su padre o madre, y a falta de ellos, de los sustitutos que ahí se indican. En este orden, para los menores adultos que se encuentren en ese tramo de edad se requeriría la voluntad del representante y del

${ }^{79}$ Ejemplo de esto lo constituye la Ley Orgánica española sobre la materia, que en su artículo $3^{\circ}$ entrega directamente al menor o incapaz la facultad de consentir el uso de su imagen, siempre y cuando tenga las condiciones mínimas de madurez para ello. Y en caso contrario, exige no solo la anuencia del representante legal, sino que además que se ponga el consentimiento proyectado en conocimiento del Ministerio Fiscal, el que tendrá 8 días para oponerse (y en caso de oposición, resuelve el juez). Sin perjuicio de que se trata de un procedimiento relativamente engorroso, es destacable que entregue al titular de la imagen la posibilidad de decidir si acepta o no su uso por un tercero, en la medida de que tenga el discernimiento suficiente. La doctrina francesa se inclina por una solución similar, al amparo del artículo 371-1 del Código Civil, que al regular la patria potestad dispone que los padres deben permitir a sus hijos participar en las decisiones que les afecten, según su edad y grado de madurez (véase Ollard n. 20), pp. 353-354). Para una exposición acabada de este tema en diferentes Ordenamientos comparados, véase Vendrell (n. 8), pp. 302 y sgtes.

${ }^{80}$ Aunque no total. Existen normas relativas a menores o incapaces que se pueden relacionar -indirectamente- con esta materia. Entre estas, el artículo $5^{\circ}$ de la Ley $\mathrm{N}^{\circ} 20.584$ (Regula los derechos y deberes que tienen las personas en relación con acciones vinculadas a su atención en salud), que exige la autorización escrita del paciente o de su representante legal para la toma de fotografías, grabaciones o filmaciones para usos o fines periodísticos o publicitarios; y el artículo 33 de la Ley $\mathrm{N}^{\circ} 19.733$, que prohíbe expresamente la divulgación, por cualquier medio de comunicación social, de la identidad de menores de edad que sean autores, cómplices, encubridores o testigos de delitos, o de cualquier otro antecedente que conduzca a ella.

${ }^{81}$ En este sentido: Ríos, S. La protección civil del Derecho a la Intimidad. LexisNexis, Santiago de Chile, 2003 , p. 49 (para el derecho a la intimidad, y con aprehensiones en relación con una eventual oposición del representado); Nogueira (n. 10) p. 271. En una posición más estricta puede encontrarse a Lathrop (n. 86 p. 944), quien exige mayor "protagonismo" al representado, y se inclina por recurrir a la representación solo como excepción.

${ }^{82}$ Nogueira (n. 10), p. 271. Corral afirma que al amparo del artículo 222 del Código Civil debe cuidarse al prestar la autorización en no dañar el interés del representado, y que en el caso del menor adulto sujeto a curaduría, podría recurrir al defensor de menores si el curador pretende autorizar una invasión a su intimidad, sin su consentimiento, según lo dispuesto en el artículo 441 del Código Civil (Corral [n. 15] p. 171).

${ }^{83}$ Corral (n. 15$)$ p. 171. 
representado. Sin embargo, se trata de una propuesta de lege ferenda, que requeriría una intervención legislativa. De momento, sin perjuicio de procurar proteger el "interés superior" del representado (que solo tendría respaldo normativo para los menores, y no los incapaces en general), la autorización estaría radicada en los representantes legales. Por su naturaleza, no podría ser tácita ${ }^{84}$, de manera que no exista duda alguna de que se ha autorizado el uso de la imagen.

Ocasionalmente nuestros Tribunales se han visto enfrentados a conflictos por utilización de imágenes de menores, y los han resuelto de una forma similar a la descrita precedentemente. Entre estos es destacable el caso Araneda con Cuevas ${ }^{85}$. Si bien se refiere al uso y difusión de imágenes, lo relevante fue el contexto en que se habían captado, y las conductas a las que quienes divulgaron las imágenes, asociaban a los menores. Se revocó la sentencia de primera instancia, acogiendo un recurso de protección interpuesto en nombre de dos menores (14 y 13 años), en contra del administrador de un grupo o página de la red social Facebook, en la que se mostraba una fotografía en la que aparecían los menores a la salida de un supermercado con un carro lleno de mercaderías, mientras se llevaban a cabo saqueos en el mismo lugar, tras el terremoto del 2010. En la página web se hizo varios comentarios e insultos que degradaban a los menores, circunstancia que, sobre todo a la luz de la Convención sobre Derechos del Niño y Adolescente ${ }^{86}$, implicó que se calificase la conducta del recurrido como ilegal y arbitraria. En ese orden, la relevancia de la sentencia a estos efectos es menor, atendido que no hay consideraciones respecto de la disposición de la imagen por parte de los recurrentes (claramente no se solicitó su autorización $)^{87}$. Y merece citarse también el caso Yáñez con Distribuidora Importadora Laibe ${ }^{88}$, sobre uso no autorizado en materia publicitaria, de la imagen de un menor en un periódico. Su madre recurrió de protección, logrando que se ordenase a la recurrida abstenerse de continuar utilizando una imagen que originalmente se captó

\footnotetext{
${ }^{84}$ Nogueira (n. 10) p. 271.

${ }^{85}$ Sentencia de la Corte Suprema del 19 de agosto de 2010.

${ }^{86}$ Específicamente de su artículo 40, que contiene garantías a los niños en relación con procesos penales.

${ }^{87}$ Un caso similar (aunque con adultos también como recurrentes, motivo que quizás implicó que
} no se invocase la Convención Sobre Derechos del Niño) se presentó en Obando y otros con Saldivia (sentencia de la Corte de Apelaciones de Punta Arenas, del 5 de octubre de 2015). Recurrió de protección una mujer por sí y en nombre de sus 4 hijos menores, en contra de una persona que había asociado una fotografía de todos los recurrentes en una red social, a un supuesto incumplimiento contractual. Esta circunstancia había motivado descalificaciones y amenazas contra los recurrentes, hechos que configuraron, a juicio de la Corte, que se vulnerase el artículo 19 en sus números 1, 4 y 24 de la Constitución. Es posible destacar que la fotografía había sido originalmente publicada por la propia recurrente, y luego utilizada por la recurrida con la finalidad indicada, en otra página web diferente.

${ }^{88}$ Sentencia de la Corte Suprema del 16 de diciembre de 2011. Si bien en un principio se invocó el artículo 19 número 4 de la Constitución, bajo la afirmación de que el derecho a la imagen formaba parte del derecho a la vida privada, a la postre se fundamentó la decisión en la protección al derecho de propiedad. La Corte señaló que en los hechos se privó a su titular de la posibilidad de obtener un legítimo aprovechamiento derivado del empleo de su propia imagen con fines de publicidad o de cualquier otro uso lícito que pudiere reportarle algún beneficio económico (considerando $12^{\circ}$ ). En primera instancia la Corte de Apelaciones de Coyhaique había rechazado el recurso (por resolución de 3 de octubre de 2011). 
con autorización de la recurrente. Más allá de las vicisitudes del recurso (que se centran en calificar la eficacia de la autorización primitiva para captar la imagen, como justificación para difundirla) ${ }^{89}$, debe tenerse presente que la Corte no cuestionó la legitimación para autorizar el uso de la imagen del menor, entendiendo que ella le corresponde al representante del menor.

\section{CONCLUSIONES}

En primer lugar, es posible afirmar que en el contexto normativo nacional existen antecedentes que contienen fundamentos explícitos que, al menos en ciertas materias, legitiman actos o contratos relativos al uso de imágenes de personas. Si bien se trata de disposiciones que en algunos casos combinan actos de autorización con contratos de transferencia o explotación, sin mayores precisiones, debieran ser suficientes para -al menos- sustentar la validez de negocios jurídicos con ese objeto, celebrados en contextos ajenos a los regulados. Esto, teniendo en consideración que si bien se trata de normas que regulan áreas o materias especiales, su tenor no es excepcional (no habría razones que justifiquen una interpretación restrictiva), y además, que pese a los postulados teóricos que impedirían actos sobre el derecho a la imagen, no hay una norma que establezca una prohibición en términos generales. Como se pudo apreciar, es posible incluso identificar explicaciones satisfactorias que justifican la procedencia de actos unilaterales y contratos sobre el derecho a la imagen, que se pueden invocar sin inconvenientes en el contexto normativo chileno.

Ahora, en la práctica estos actos podrán ser, según el caso, autorizaciones unilaterales -las que serán siempre revocables-, o contratos en los que el titular del derecho a la imagen contrae un deber de abstención y tolerancia respecto de determinados actos a realizarse por su co-contratante, los que en principio no serían revocables. Pero en ningún caso podría defenderse la validez de la transferencia del derecho a un tercero, por tratarse de un derecho inalienable. Por otra parte, la obligación de indemnizar perjuicios en supuestos de revocación (que suele entenderse procedente en el caso de los actos unilaterales), debiera regirse por las reglas generales, y no concederse fundada solo en el acto de revocación.

Por último, cuando el titular del derecho es un incapaz, sin perjuicio de los motivos que puedan inducir inicialmente a otorgar cierta permisividad cuando aquel ostenta la madurez suficiente para ello, de momento la realidad normativa chilena entrega el control de los actos de autorización a su respectivo representante legal. Sin embargo, cuando se trata especialmente de menores, debe tenerse presente siempre que la protección del “interés superior del niño”, puede conducir a justificar una revisión judicial del acto autorizante (debiendo el juez, en su caso, velar porque se haya cuidado el interés del

${ }^{89}$ Y respecto de la legitimación pasiva del recurso, en consideración a que las imágenes fueron captadas por un tercero, que luego habría cedido las imágenes a la recurrida. 
representado). En suma, en estas hipótesis debieran interpretarse las normas siempre con prudencia, procurando no afectar en forma alguna la dignidad del incapaz.

\section{BiBLIOGRAFÍA}

Agate, A., "Il Diritto all'Immagine”, en Ruscica, S. I Diritti della personalità, Wolters Kluwer, Lavis, 2013.

Alessandri R., A; Somarriva U., M. Curso de Derecho Civil. Parte General y los Sujetos de Derecho, por Antonio Vodanovic H., Editorial Nascimento, Santiago, 1971.

Barros, E., Tratado de Responsabilidad Civil, Editorial Jurídica de Chile, Santiago, 2006.

Bertrand, A., Droit à la vie privée et droit à l'image, Litec, París, 1999.

CASTALDI, C., L'Exploitation commerciale de l'Image des personnes physiques, Bruylant, Bruselas 2008.

Castán, J., "Los derechos de la personalidad", en Revista General de Legislación y Jurisprudencia, vol. XXIV, $\mathrm{n}^{\circ} 1-2,1952$

Clavería, L.H., "Negocios jurídicos de disposición sobre los derechos al honor, la intimidad y la propia imagen”, en Anuario de Derecho Civil, vol. XLVII, n III, 1994.

CONCEPCión Rodríguez, J.L., Honor, intimidad e imagen, Bosch, Barcelona, 1996.

Corral, H., "La vida privada y la propia imagen como objetos de disposición negocial", en Revista de Derecho de la Universidad Católica del Norte, $\mathrm{n}^{\circ}$ 8, 2001.

De Ángel, R., "La protección de la personalidad en el Derecho Privado", en Revista de Derecho Notarial. (XXI), no LXXXIII, 1974

De Cupis, A., I Diritti della Personalità. Giuffrè, Milán, 1959, tomo I.

De Verda y Behamonte, J.R., "El consentimiento como causa de exclusión de la ilegitimidad de la intromisión”, en De Verda y Behamonte, J.R, El Derecho a la Imagen desde todos los puntos de vista, Thomson Reuters, Navarra, 2011.

Galgano, F., Diritto Civile e Commerciale, Cedam, Padova, 2004, vol. I.

Gitrama, M., "Voz 'imagen (derecho a la propia)", en Mascareñas, C.; Pellisé, B. Nueva Enciclopedia Jurídica, Seix, Barcelona, 1979.

Goubeaux, G., Traité de Droit Civil sous la direction de Jaques Ghestin. Les personnes, Librairie générale de droit et de Jurisprudence, Paris 1989.

Grimalt, P., La protección civil de los derechos al honor, a la intimidad y a la propia imagen, Iustel, Madrid, 2007.

GuZMán, A., Las cosas incorporales en la doctrina y en el Derecho Positivo, Editorial Jurídica de Chile, Santiago, $2^{\mathrm{a}}$ edición.

Hassler, T., Le droit à l'image des personnes: entre droit de la personnalitè et propriété intellectuelle, LexisNexis, Estrasburgo, 2014.

IgaRtuA, F., "El derecho a la imagen en la jurisprudencia española", en Salvador, P. (dir.), El mercado de las ideas, Centro de Estudios Constitucionales, Madrid, 1990.

Kayser, P., "Le droits de la personnalité. Aspects Théoriques et pratiques", en Revue Trimestrielle de Droit Civil, 1971, vol. 69.

Lathrop G., Fabiola, "El derecho a la imagen de niños, niñas y adolescentes en Chile", en Revista Chilena de Derecho, vol. 40, n 3, 2013.

Le Tourneau, P., Droit de la responsabilité et des contrats. Régimes d'Indemnisation, Dalloz, Paris, 2014.

Martín, A., "El contenido patrimonial del derecho a la propia imagen", en Revista de Derecho Mercantil, $\mathrm{n}^{\circ}$ 242, 2001. 
Masson, J., "Le droit à l'image”, en Renchon, J.L., Les droits de la personnalité, Bruylant, Bruselas, 2009 .

Nogueira, H., "El derecho a la propia imagen como derecho fundamental implícito. Fundamentación y caracterización", en Revista Ius et Praxis, $\mathrm{n}^{\circ}$ 2, 2007.

Nogueira, P., El derecho a la propia imagen, Librotecnia, Santiago, 2010.

Ollard, R., "Qualification de droits extrapatrimoniaux", en Saint-Pau, J.C., Droits de la Personnalité, Lexisnexis, Paris, 2013.

PEÑA, J.I., "El derecho a la propia imagen en la doctrina y jurisprudencia chilenas", en Revista de Derecho Público, n 63, tomo I, 2001.

PEÑA, J.I., "El derecho a la propia imagen en la doctrina y jurisprudencia chilenas", en Revista de Derecho Público, nº 64, 2002.

PeÑAIlillo, Daniel, Obligaciones, Editorial Jurídica de Chile, Santiago, 2003.

Prosser, W., "Privacy", en California Law Review, vol. 48, 1960.

Ríos, S., La protección civil del Derecho a la Intimidad. LexisNexis, Santiago de Chile, 2003.

Rodríguez, J.M., "Autorización y cesión: el consentimiento para la intromisión en derechos inalienables", en Cabanillas, A.; Caffarena, J. Estudios jurídicos en homenaje al profesor Luis Diez-Picazo, tomo I, Thomson Civitas, Navarra, 2003.

Rovira, M.E., "El derecho a la propia imagen: Configuración legal y límites", en Revista de Derecho Privado, no 2, 1998.

Vendrell, C., El Mercado de los Derechos de Imagen, Thomson Reuters, Navarra, 2014.

Westfall, D.; Landau, D., "Publicity Rights as Property Rights", en Cardozo Arts E Entertainment, vol. 23, 2005.

YzQuierdo, M., "Daños a los derechos de la personalidad (honor, intimidad y propia imagen)", en Reglero, L., Tratado de responsabilidad civil, $5^{a}$ edición, Thomson Aranzadi, Navarra, 2014. 